\title{
Lao People's Democratic Republic
}

National Cancer Institute

\section{Source}

National Cancer Institute. Lao People's Democratic Republic. NCI Thesaurus. Code C16780.

A country in southeastern Asia, north and east of Thailand, west of Vietnam. 